\title{
AZ ALKATRÉSZ KFT. KÉSZLETEZÉS HATÉKONYSÁGÁNAK VIZSGÁLATA
}

\author{
Fazekas Andrea
}

\begin{abstract}
Absztrakt: Cikkemben egy hazai vállalat, az Alkatrész Kft. készletgazdálkodásának hatékonyságát vizsgálom. A vállalkozás két üzlethelyisége mellett több raktárt és letéti készletet is tart, így a cég vagyonának meghatározó része áll a készleteiben. A Kft. készletgazdálkodásának hatékonyságát a készletek forgási sebessége, az átlagos raktározási idő és a készlethatékonysági mutató kiszámításával elemzem. A vizsgálathoz szükséges adatokat és információkat egy strukturált interjú keretében kaptam meg a cég kereskedelmi vezetöjétöl. A számítások elvégzése közben azt tapasztaltam, hogy a vállalkozás készletgazdálkodása nem túl hatékony. Ez nem feltétlenül jelenti a vállalat kudarcát, viszont célszerü lenne a termékek értékesítésének fellendítésre megfelelö marketing stratégiát alkalmazni, valamint mielőbb értékesíteni a nagy értékü speciális gyártású termékeket.
\end{abstract}

\begin{abstract}
I examined the effectiveness of inventory management of a domestic company, Alkatrész $\mathrm{Kft}$. in my article. The company holds two premises, several warehouses and custodial inventory. The major part of the company's assets is in stock. The company's efficiency of inventory management was analysed by the calculation of Set Efficiency Index, stock turnover and average storage time. I received the necessary data and information from the company's commercial manager via a structured interview. While performing the calculations, I found that the enterprise inventory management is not very effective. This does not necessarily mean the failure of the company, but it would be advisable to correct the marketing strategy and sell the high-value special products as soon as possible.
\end{abstract}

Kulcsszavak: készletezés, készlet forgási sebesség, átlagos raktározási idő, készlethatékonysági mutató

Keywords: stockpiling, average storage time, average storage time, Set Efficiency Index

\section{Bevezetés}

$\mathrm{Az}$ eszközökön belül megkülönböztetjük a befektetett eszközöket a forgóeszközöktől. A befektetett eszköz éven túl szolgálja a vállalkozás tevékenységét. Ezen belül beszélhetünk tárgyi eszközökről és immateriális javakról. A tárgyi eszközökbe való befektetést hívjuk beruházásnak (Zsótér et al., 2014). A beruházásokat többféleképpen csoportosíthatjuk, ezek közül kettőt említenék: a termelő beruházást és az infrastrukturális beruházást (Zsótér-Tóth, 2014). A forgóeszközök közvetlenül vagy közvetve, általában egy évnél rövidebb ideig szolgálják a vállalkozás tevékenységét. A készletek rendszerint egyetlen tevékenységi folyamatban vesznek részt. Eredeti megjelenési formájukat elveszítik, vagy változatlan állapotban maradnak, bár értékük változhat. A készletek közé tartoznak az állatok is (a tenyészállatokat kivéve), függetlenül attól, hogy a vállalkozás tevékenységét mennyi ideig szolgálják (Adorján et al., 2009).

Jelen cikk keretein belül azt szeretném megvizsgálni, hogy hogyan tudja egy kereskedelemmel foglalkozó kisvállalat, az Alkatrész Kft. készletgazdálkodási módszereinek felülvizsgálatával a versenyképességét megőrizni, illetve tovább növelni. A vizsgálat során készletgazdálkodási mutatók segítségével elemzem a vállalkozás tevékenységét. 


\section{A készletgazdálkodással kapcsolatos legfontosabb ismeretek}

\subsection{Alapfogalmak}

Minden vállalkozást általában a lehető legnagyobb árbevétel elérése érdekében alapítanak, ahol a fó bevétel szolgáltatásnyújtásból és/vagy termékértékesítésből ered. Számviteli értelemben terméknek minősül a saját termelésü készlet, anyagkészlet és az áru. A saját termelésü készleteket azért állítja elő a vállalkozó, hogy az előállítási költségnél magasabb áron értékesítse. Az árut mindig a magasabb áron történő továbbértékesítési célból vásárolja, az anyagkészletnek pedig a termelésben és a szolgáltatásnyújtásban van szerepe. Előfordul azonban, hogy az anyagkészletet a vállalkozás továbbértékesíti, ilyenkor az anyagkészlet számviteli elszámolás szempontjából áruként fog viselkedni. Ugyanazon eszköz besorolása az egyes gazdálkodóknál különböző módon történik, mivel ahol az eszközt elöállítják, a saját termelésü eszközök közé sorolják, azonban akik megvásárolják már vásárolt készletként tartják nyilván. A készletek között.megkülönböztethetünk termelési célú és eladási célú készleteket is (Korom et al., 2005).

Számviteli szempontból tehát a készleteket két csoportba sorolhatjuk:

- Saját termelésú készletek

- Vásárolt készletek

A saját termelésü készletek közé sorolunk minden olyan készletet, amelyet a vállalkozás saját maga állít elö. Tehát az értékesítést megelözően valamilyen termelési folyamatban részt vesznek, vagy vettek. Továbbfelhasználásra vagy értékesítésre várnak. A tenyészállatok kivételével az állatok is a saját termelésü készletek csoportjába tartoznak.

A vásárolt készletek közé sorolunk minden olyan készletet, melyet nem a vállalkozás állít elö. Más vállalkozótól szerezi be, termelési- és továbbértékesítési célból. Ide tartoznak még a készletekre adott elölegek.

Számviteli szempontból az anyagok elhasználódási ideje egy évnél rövidebb, függetlenül attól, hogy hány megmunkálási folyamatban vettek részt. A vállalkozó az anyagokat termelési céllal vásárolja termék elöállításához, szolgáltatásnyújtáshoz. A termelés során eredeti alakjukat elveszítik, értékük az előállított termék, vagy nyújtott szolgáltatás értékében jelenik meg.

$\mathrm{Az}$ áruk olyan készletek, amelyeket a vállalkozó általában értékesítési céllal szerez be, változatlan formában értékesíti. Értékük azonban változhat.

A készletekre adott előlegek nem tartalmazzák az elözetesen felszámított áfát. Azokat az előlegeket kell ilyen címen kimutatni, amelyeket a vállalkozó a szállítónak, az importálást végzőknek, valamint a szolgáltatást nyújtónak kifizet (Szakács, 2009; Gál J., 2008).

\subsection{A készletek nyilvántartása}

A saját termelésủ készleteket közvetlen önköltségen kell kimutatni. A vállalkozó eldöntheti, hogy év közben folyamatos értékbeni és mennyiségi nyilvántartást vezet, vagy esetleg csak mennyiségi nyilvántartást. 
A saját termelésű készletek közé sorolt befejezetlen és félkész termékekről a gazdálkodónak nem szükséges analitikus nyilvántartást vezetni. Ezeket évzáráskor kell készletre venni a leltár alapján. Az anyagokat és árukat, tehát a vásárolt készleteket az éves beszámoló készítéséhez egyedileg, vagy csoportosan kell kimutatni. Ezen készleteknél a gazdálkodó eldöntheti, hogy év közben vezet e folyamatos mennyiségi és értékbeli nyilvántartást, vagy évközben nem vezet értéknyilvántartást. Ha nem vezet évközben nyilvántartást, akkor év végén a készletek értékelésekor, vagy a mennyiségi nyilvántartás alapján, ha azonban ilyet sem vezet, akkor a leltár alapján tudja meghatározni a mérlegbe tartozó anyagkészletet (Kardos et al., 2012).

$\mathrm{Az}$ Alkatrész $\mathrm{Kft}$. nem állít elő saját termelésü készleteket, kereskedelmi vállalkozás révén vásárolt készletek továbbértékesítésével foglalkozik. Készleteit a Correkt Számlázó és Készletnyilvántartó elektronikus program segítségével tartja nyilván év közben. A program a készletek mennyiségi és értékbeli nyilvántartását is nyomon követi, ám év közben többnyire csak a mennyiségi adatokat figyelik. A cég a vásárolt készleteit év végén a beszámoló elkészítéséhez csoportosan mutatja ki készletei értékelésekor, az elkészített leltár alapján.

Ha a vállalkozás elszámoló árat alkalmaz, arról külön nyilvántartást kell vezetni, melyben elő kell írnia az elszámoló ár képzését, valamit megváltoztatási szabályait. Ha a gazdálkodó elszámoló árat használ, akkor ezt a fökönyvi számlákon, vagy a mennyiségi és értékadatokat tartalmazó analitikában lehet nyilvántartani. Szuikség van arra, hogy pontosan meg lehessen határozni, hogy az elszámoló árkülönbözet mely készletcsoporthoz tartozik, ugyanis ez alapján lehet megállapítani a tényleges beszerzési árat. Az elszámoló árat szükséges idönként összehasonlítani a tényleges beszerzési árral, ugyanis ha a két ár között jelentős eltérést lát a gazdálkodó, az elszámoló árat módosítani kell, erre év közben is van lehetőség. Módosításkor az anyagkészlet összértéke nem változhat, ezért az elszámoló árkülönbözetet is meg kell változtatni, tehát amennyivel növeljük az elszámoló árat, annyival csökkentjük a különbözetet és fordítva (Kardos et al., 2012).

\subsection{A készletek értékelése}

A gazdálkodónak a számviteli politikájában rögzítenie kell, hogy a saját termelésủ készleteit és a vásárolt készleteit hogyan számolja el, valamint hogyan tartja nyilván. A készletek értékelésekor a vállalkozónak a saját termelésü készleteit előállítási önköltségen, a vásárolt készleteit beszerzési áron kell aktiválnia. Év közben bekerülési értéken tartjuk nyilván a számlákon a készleteket, míg év végén a könyv szerinti értéken kerülnek kimutatásra. Vásárolt készletek beszerzési árának meghatározása történhet tényleges beszerzési ár, valamint átlagos beszerzési ár alkalmazásával. Az Alkatrész Kft. esetében a tényleges beszerzési ár alkalmazásával határozzák meg a készletek értékét. 
Fazekas A.

I. táblázat: A készletértékelési eljárások összehasonlítása

\begin{tabular}{|c|c|c|}
\hline Megnevezés & FIFO & LIFO \\
\hline Angol elnevezés & first in - first out & last in - first out \\
\hline Jelentése & $\begin{array}{l}\text { elöször beérkezett készlet } \\
\text { kerül elöször felhasználásra } \\
\text { (kivezetésre) }\end{array}$ & $\begin{array}{l}\text { utolsónak beérkezett } \\
\text { készlet kerül először } \\
\text { felhasználásra (kivezetésre) }\end{array}$ \\
\hline Zárókészlet & utolsó árakon & első árakon \\
\hline \multicolumn{3}{|l|}{ Az átlagárhoz képest: } \\
\hline - ha az ár nö & felértékel & leértékel \\
\hline $\begin{array}{ll}\text { - } & \text { ha az ár } \\
\text { csökken }\end{array}$ & leértékel & felértékel \\
\hline $\begin{array}{l}\text { A számviteli törvény } \\
\text { szerint }\end{array}$ & $\begin{array}{l}\text { Legjobb: } \\
\text { - árcsökkenésnél jó } \\
\text { - áremelkedésnél ugyan } \\
\text { felértékel, de megfelel } \\
\text { a törvénynek, mert az } \\
\text { átlagárhoz képest értékel fel, } \\
\text { de a tényleges beszerzési árnál } \\
\text { nem értékel magasabbra }\end{array}$ & $\begin{array}{l}\text { Nem jó: } \\
\text { - áremelkedésnél jó lenne } \\
\text { - árcsökkenésénél az } \\
\text { átlagárhoz képest felértékel, } \\
\text { de felértékel a tényleges } \\
\text { beszerzési árhoz képest is, } \\
\text { ami a Szt.-nek nem felel } \\
\text { meg }\end{array}$ \\
\hline Megnevezés & LOFO & $\mathrm{HIFO}$ \\
\hline Angol elnevezés & lowest in - first out & highest in - first out \\
\hline Jelentése & $\begin{array}{l}\text { a legalacsonyabb árukészlet } \\
\text { kerül először felhasználásra } \\
\text { (kivezetésre) }\end{array}$ & $\begin{array}{l}\text { a legmagasabb árukészlet } \\
\text { kerül először felhasználásra } \\
\text { (kivezetésre) }\end{array}$ \\
\hline Zárókészlet & legmagasabb áron & legalacsonyabb áron \\
\hline Az átlagárhoz képest: & felértékel & leértékel \\
\hline $\begin{array}{l}\text { A számviteli törvény } \\
\text { szerint }\end{array}$ & $\begin{array}{l}\text { - ártendenciától függetlenül } \\
\text { mindig felértékel az } \\
\text { átlagárhoz képest } \\
\text { - mindig a legmagasabb áron } \\
\text { beszerzett készlet marad } \\
\text { raktáron, ami értékelési } \\
\text { szempontból a Szt.-nek nem } \\
\text { felel meg }\end{array}$ & $\begin{array}{l}\text { - ártendenciától függetlenül } \\
\text { aláértékel az átlagárhoz } \\
\text { képest } \\
\text { - a Szt.-nek nem felel meg } \\
\text { - a valódiság elve alapján a } \\
\text { mérlegérték jelentôsen } \\
\text { eltérhet a piaci értéktől }\end{array}$ \\
\hline
\end{tabular}

Forrás: Adorján (2009)

Tényleges beszerzési ár alkalmazása esetén a készleteket a vállalkozás tényleges elöállítási költségen, illetve beszerzési áron tartja nyilván, amennyibe az a vállalkozásnak ténylegesen került. Az év közben elöállított és beszerzett készletek egyedileg a tényleges bekerülési értéken kerülnek rögzítésre a vállalkozás fökönyvi számláin. Az 1. táblázat szemlélteti a tényleges beszerzési ár esetén a készletértékelési eljárások összehasonlítását.

$\mathrm{Az}$ átlagos beszerzési ár alkalmazása esetén külön kell kezelni a tényleges beszerzés értékét, valamint a készletek raktárra vételekor használt értéket. Olyan vállalkozóknál érdemes alkalmazni, ahol több szállítótól származik a beszerzés, így 
az egyes termékek beszerzési értéke eltér. Ebben az esetben a készletek tényleges bekerülési értékét számolással lehet megállapítani:

- Súlyozott átlagár számítása esetén a bekerülési értéket minden alkalommal a beszerzett mennyiség és annak egységár szorzata adja meg. Felhasználáskor számított beszerzési értéket állapítanak meg a felhasználásra jutó mennyiségre és ezen az értéken könyvelik le a felhasználást. A számított átlagos beszerzési ár lehet csúsztatott átlagár (ebben az esetben minden beszerzés után újra kiszámítják az átlagos beszerzési árat) vagy pedig éves átlagár (ebben az esetben az átlagos beszerzési árat időszakonként újraszámítják, és ez alapján határozzák meg a készletcsökkenések értékét).

- Elszámoló ár számítása esetén a vállalkozó egy elöre meghatározott elszámoló áron veszi raktárra a készleteit. Ebben az esetben minden készletmozgás ezen az áron kell lekönyvelni. Az elszámoló ár és a beszerzési ár közötti különbözetet az árkülönbözet számlán mutatja ki a vállalkozás (Bíró et al., 2012).

2.4. Készletezési mechanizmusok

A gyakorlatban alkalmazott készletezési mechanizmusok között alapvetően két alaptípust különböztetünk meg, amelyekre az összes többi változat épül. Ezek a folyamatos és a periodikus készletvizsgálat.

A folyamatos készletvizsgálati rendszer úgy müködik, hogy állandóan figyelni kell a készletszint alakulását, és amikor az egy elöre meghatározott szint alá süllyed, akkor adjuk le a rendelést. A két rendelés között eltelt idő ez esetben a kereslet nagyságától függ. Tehát különböző időszakonként fogunk azonos mennyiségü terméket rendelni. Ezt az általánosan elfogadott rövidítések szerint Q,s rendszernek, vagy állandó rendelési tétel-nagyság rendszernek is szokás nevezni. Ennek szemléltetésére az 1. ábra szolgál, ahol az „,s" a meghatározott készletszint, aminek elérésekor a rendelést le kell adni, a „Q” az állandó rendelési tétel-nagyság, az „L” pedig az utánpótlási idő. 


\section{1. ábra: A folyamatos készletvizsgálat készletszint diagramja}

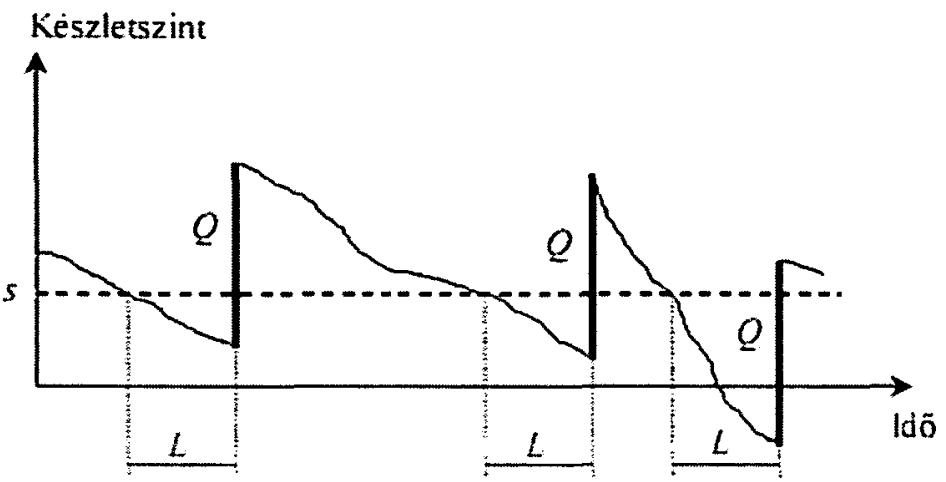

Forrás: Koltai (2006)

A második alaptípus pedig a periodikus készletvizsgálat, melynek lényege, hogy meghatározott rendelési periódusonként töltjük fel a készleteket egy elöre meghatározott szintre. Ebben az esetben tehát azonos időszakonként rendelünk, viszont a rendelési tétel nagyságát a két rendelés között felmerülő kereslet mértéke határozza meg, így azok rendelésenként különbözö nagyságúak lesznek. Ezt a rendszert a szakirodalom S,R rendszernek, is nevezi. Ennek múködését mutatja be a 2. ábra, ahol az „ $\mathrm{R}$ ” a készletfigyelési periódus, az „, '” a maximális készletszint, a Q1, Q2, Q3 pedig a rendelési tételek nagyságát jelöli (Koltai, 2006).

\section{2. ábra: A periodikus készletvizsgálat készletszint diagramja}

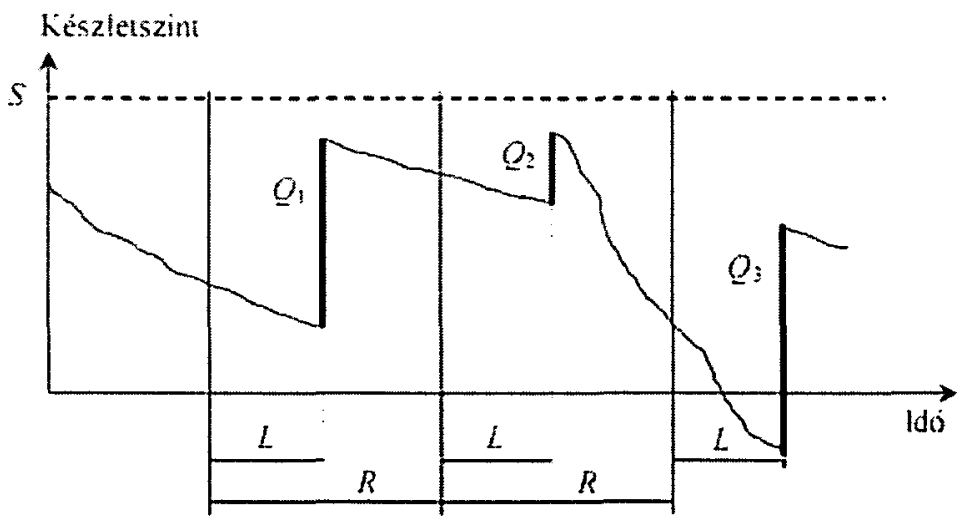

Forrás: Koltai (2006)

A két bemutatott mechanizmus között két lényeges eltérés tapasztalható. Az egyik, hogy a folyamatos készletvizsgálat rugalmasabban reagál az igény változásaira, így a hiány elöfordulásának kockázata kisebb. Ez esetben a veszélyes időtartam csupán az utánrendelési idö, mert ha a megrendelés és a beérkezés közötti időszakban váratlanul megnövekszik a kereslet, akkor hiány alakulhat ki. Ezzel szemben a periodikus készletvizsgálat esetén a rendelési periódus megnövelve az 
utánpótlási idővel, számít veszélyes időszaknak. A másik különbség az, hogy a periodikus készletvizsgálat szervezése egyszerübb. A korszerü informatikai rendszerek ugyan nagyban megkönnyítik a folyamatos készletvizsgálatot, de müködése így is több szervezömunkát és ez által nagyobb ráfordítást igényel, mint a periodikus készletvizsgálat (Bányainé et al., 2016).

$\mathrm{Az}$ Alkatrész Kft. esetében, ami a készletezést illeti mind a periodikus, mind pedig a folyamatos készletvizsgálatot alkalmazzák. Folyamatos készletvizsgálatot alkalmaznak a vállalkozás két üzletében, valamint a cég 3 raktárában. Ebben az esetben napi szinten tisztában vannak a készleten lévő mennyiségekkel minden termék esetében és bármikor tudnak utánrendelni, készletet feltölteni. Azonban periodikus készletvizsgálatot alkalmaznak a cég nagyobb üzleti partnereinél elhelyezett letéti készleteknél. Mivel ezek a partner cégek nagyobb termelő üzemek, így egy komoly kiesést jelentene számukra egy-egy alkatrész meghibásodása miatti termelés leállás. A letéti készlet előnye, hogy az Alkatrész Kft. termékeit egy elzárt szekrényben elhelyezi a fö partnereinél, így azok egy gépsor meghibásodása esetén azonnal fel tudják használni azokat, akár éjszaka is. A felhasznált alkatrészeket jelentik az Alkatrész Kft.-nek, aki az aktuális árfolyamon kiszámlázza azt a felhasználónak, majd újratölti a letéti készletet. A biztonság kedvéért azonban havi szinten készletvizsgálatot (leltárt) is végeznek a letéti készletek esetében.

\subsection{A készlettartás költségei}

A készlettartással kapcsolatban felmerülő költségek között megkülönböztetjük azokat, amelyek a készletgazdálkodási döntések szempontjából lényegtelenek, vagyis nincsen rájuk befolyással az, hogy miből, mikor, mennyit rendelünk, valamint megkülönböztetjük azokat a lényeges költségeket, amelyeket viszont mindezek a döntések kisebb, vagy nagyobb mértékben befolyásolnak. Az Alkatrész Kft. esetében a 3 raktárhelyiség fenntartása a készletezési döntések szempontjából lényegtelen költség, mert függetlenül attól, hogy a raktár üres, vagy tele van, akkor is kell fizetni fix költségeket a raktár után.

A lényeges költségek körét pedig négy fö csoportra oszthatjuk:

- Az első csoportba tartoznak a beszerzési költségek, azaz az áru megvásárlásakor, illetve legyártásakor keletkező költségek. Ezeket akkor tekinthetjük lényegesnek, ha nagyságuk függ az egyszerre vásárolt mennyiségtől (pl. mennyiségi árengedmény esetén). Ellenkező esetben lényegtelenek lesznek, mert előbb, vagy utóbb mindenképpen ki kell fizetni az egész mennyiséget, függetlenül attól, hogy mikor érkezik meg.

- A második csoportba a rendelési költségek sorolhatóak, vagyis az áru megrendelésének lebonyolításakor, valamint a rendelés beérkezésekor felmerülő költségek. Ebbe egy kereskedelmi vállalat esetében beletartozhatnak például az adminisztrációs költségek, a fuvarköltségek, vagy a minőség-ellenőrzés költségei.

- A harmadik a készlettartási költségek csoportja. Ebbe azok a költségek tartoznak, amelyek a készletszinttel egyenes arányban mozognak, vagyis 
akkor nönek, ha a készletszint nö, és csökkennek, ha a készletszint csökken. Ezeknek legnagyobb részét a tökelekötés költsége teszi ki.

- A negyedik csoport a hiányköltségeké. Ebbe a hiány keletkezésekor felmerülő költség és az elmaradt hozam tartozik bele, valamint a vevöi elégedetlenség miatt a cég hírnevének esetleges romlása. Ezek a költségek a legnehezebben számszerüsíthetök (Kövesi, 2009).

Ezeket a költség kategóriákat célszerü tehát figyelembe venni és megvizsgálni egy-egy termék készletezésével kapcsolatos operatív döntések kidolgozásánál. Az Alkatrész Kft.-nél a fent felsorolt készlettartásban lényeges költségek közül a beszerzési költség hatása elenyésző a készletgazdálkodással kapcsolatos döntésekre, mert a rendelések elenyésző hányadában kapnak a rendelésre mennyiségi árkedvezményt. A fizikai avulás sem jelentős költség, mivel nem romlandó terméket értékesítenek. Ami a rendelési költségeket illeti, a fuvarozás költsége komolyabb jelentőséggel bír beszállítóik kiválasztásakor, illetve készleteik utánpótlásakor, különös tekintettel a külföldről beszerzett termékek esetén. Ezért a nagyobb mennyiségü és/vagy nagyobb méretủ termékek beszerzésekor (melyek több $100 \mathrm{~kg}$ osak is lehetnek) több beszállítótól is kérnek árajánlatot, illetve egy beszállítón belül több szállítási mód költségének utánajárnak. Személyi kapacitásuk szükössége miatt azonban nem sikerül minden esetben az összes beszerzési lehetőség rendelési költségét felmérni, így időnként nem sikerül megállapítani, hogy melyik az adott esetben a gazdaságos megoldás. Emiatt a közeljövőben fontos lesz ezeknek a mérésére vonatkozó módszertan kidolgozása, majd pedig alakulásuk folyamatos nyomon követése, mert a vállalat bövülésével egyre nehezebbé válik azt megvalósítani, hogy egy ember átlássa valamennyi termékre vonatkozóan az összes figyelembe veendő költségtényezöt.

\section{Kutatási módszerek a készletezés hatékonyságának vizsgálatára}

A vizsgálatok során a módszertani háttér ismertetése és esetleges továbbfejlesztése elengedhetetlen (Zsótér, 2008). A számos módszer közül a strukturált interjút választottam, melyet az Alkatrész Kft. kereskedelmi vezetőjével készítettem, 2017. március 6-án, a vállalkozás szegedi irodájában. Az interjú szóbeli megkérdezésen alapuló kutatási módszer, amely az adatgyüjtés során a szubjektív vélemények kifejtésére alkalmas (Babbie, 1999). A strukturált interjú előre megtervezett szerkezet szerint összeállított kérdések sorát jelenti, melynek célja elsősorban a kvantitatív információgyüjtés. Ez a módszer sok szempontban hasonlít a kérdöíves módszerhez, de az interjúalanynak a személyes beszélgetés során lehetősége nyílik véleményének mélyebb kibontására és az elhangzott információk pontosítására (Majoros, 2004.).

Az Alkatrész Kft. egy 1991-ben létrejött kereskedelmi vállalkozás. A cég 8 föt foglalkoztat fóállásban. A cég egy $70 \mathrm{~m}^{2}$-es gazdasági irodával, egy $70 \mathrm{~m}^{2}$-es kereskedelmi irodával, egy $300 \mathrm{~m}^{2}$-es szegedi és egy $200 \mathrm{~m}^{2}$-es kecskeméti üzlettel, valamint 3 db $60 \quad \mathrm{~m}^{2}$-es raktárral rendelkezik. A vállalkozás kizárólag kereskedelemmel foglalkozik, termelő tevékenységet nem folytat, tehát tisztán készletező rendszert müködtet. Termékeit belföldre és külföldre egyaránt értékesíti. 
A Kft. fö tevékenysége csapágyak, szimeringek és ipari alkatrészek értékesítése, tehát tevékenységére nem hat a szezonalitás. Az Alkatrész Kft. fö üzleti partnerei a következö cégek (melyeknél letéti készletet tart): Prizmian MKM Kft., Szeplast Zrt., Fémépszer Kft., Fóliaplast Kft., Sole.-Mizo Zrt., Pick Szeged Zrt., DAKK Zrt., Dunapack Kft., Hamburger Hungária Kft. Mindemellett a személyes vásárlókat is kiszolgálják mindkét üzlethelyiségében, ahol a kiskereskedelmi forgalmazással párhuzamosan megjelenik a viszonteladóknak történő értékesítés is.

A cég termékeiböl kiderül, hogy a kereslet mértéke (az üzleti partnereknek való alkatrész beszállítás) sok esetben egy hirtelen fellépő igény, meghibásodás okán merül fel. Ennek következtében a vásárlónál gyártás leállás történik, így kulcsfontosságú szerepet tölt be a kiszállítás gyorsasága. Fontos tehát, hogy raktáraiban napi szinten megfelelő készlet álljon rendelkezésére, amivel az összes felmerülő igényt ki tudja elégíteni. Tehát a készletezési stratégiát az egyes termékcsoportokra és termékekre lebontva e szempontok figyelembevételével célszerü meghozni.

A következőkben az Alkatrész Kft. készletezését a következő készletgazdálkodási mutatókkal fogom megvizsgálni:

- készletek forgási sebessége

- átlagos raktározási idő

- készlethatékonyság mutató.

A készletek forgási sebessége az egyik legáltalánosabban használt mutató, amit a készletekkel kapcsolatban vizsgálni szokás. A készletek forgási sebessége az áruforgalom hatékonyságát mutatja meg, vagyis azt, hogy milyen gyorsan fordul meg a készletünk. Minél kevesebb idő alatt fordul meg a készlet, annál nagyobb a készletek forgási sebessége.

Ennek kiszámítása a következőképpen történik:

Készletek forgási sebessége $=\frac{\text { értékesített készletek önköltsége }}{\text { átlagos készletérték }}$

vagyis: Fordulatszám $=\frac{\text { nettó árbevétel }}{\text { átlagos készletállomány }}$

Tehát az adott időszakban értékesített készletek önköltségét kell elosztani az adott időszak alatt készleten tartott termékek átlagos értékével. Minél nagyobbra jön ki ez a hányados, annál gyorsabban jön vissza a termékekbe befektetett pénz.

A gyors forgási sebesség elönyei közé tartozik, hogy kisebb kamatköltséggel és kisebb hiteligénnyel jár, ha hitelböl finanszírozza a vállalkozás a forgalom egy részét. Ezen felül kisebb a biztosítási költség, amennyiben a készletek biztosítása szükséges, valamint kisebb a helyigény a tárolásra. Mindemellett természetesen nő az értékesítés, és újabbak a készletek, ami csökkenti a minőségromlás és az elavulás kockázatát, és marketing szempontból sem elhanyagolható tényezö. Ugyanakkor a gyors forgási sebességnek vannak hátrányai is. Mivel nagyobbak a beszerzéssel kapcsolatos költségek a kisebb rendelési tételnagyság miatt nagyobbak lehetnek a 
hiány miatti veszteségek, és a kisebb készletek miatt értékesítés eshet ki (Bíró et al., 2005).

Ugyanennek a mutatónak egy más megközelítésből felírt változata az átlagos raktározási idő, ami a nevéböl is láthatóan nem a fordulatszámot mutatja meg, hanem azt, hogy átlagosan hány napot vesz igénybe, mire a készletek egyszer megfordulnak.

Az átlagos raktározási idő kiszámítása a következőképpen történik:

Átlagos raktározási idő= $\frac{\text { átlagos készletérték }}{\text { ELÁBÉ/365 }}$

vagyis: Forgási sebesség napokban $=\frac{\text { átlagos készletérték } \cdot \text { napok száma }}{\text { nettó árbevétel }}$

Ebben az esetben tehát az egyre alacsonyabb számok fogják jelenteni az egyre gyorsabb megtérülési időt, azaz a gyorsabb forgási sebességet (Coyle et al., 1992).

$\mathrm{Az}$ Alkatrész Kft. készleteinek (minden raktárát és üzletét figyelembe véve) átlagos forgási sebessége az elmúlt egy évben 5,29 volt, vagyis az átlagos raktározási idő 68,94 napra jött ki, ami viszonylag lassúnak számít. A lassú forgási sebesség a gyenge eladás jele lehet, tehát fölösleges mértékü készletet is jelent. A magas készletállomány nem jó, mivel a cég jelentős mértékü készpénzt köt le, így veszélyt is jelenthet a cégnek, amennyiben az árak esni kezdenek. Az Alkatrész Kft. nagyon sokféle terméket értékesít. Termékskáláján találhatunk néhány száz Ft-os csapágyakat, de több millió Ft-ot érő alkatrészeket is. A cég készletének forgási sebességét nagymértékben lelassíthatják a nagy értékü elfekvő árukészletek. Ezek megléte persze önmagában még nem jelenti a vállalat kudarcát, viszont ahhoz, hogy a forgási sebesség növekedni tudjon, első lépésként fontos ezen a termékek értékesítésének fellendítésre megfelelö marketing stratégiát alkalmazni. Egy bizonyos szint után egyébként nem feltétlenül cél a forgási sebesség további növelése, mert az zavarokat okozhat más területeken, ahogyan korábban már említettem a gyors forgási sebesség hátrányainál. A forgási sebesség nagyságát leginkább az érintett gazdasági szektor sajátosságai befolyásolják, ezért a kívánatos forgási sebesség értékét elég nehéz meghatározni. Mindenesetre irányadó lehet, hogy a kis és nagykereskedelmi vállalatoknál ez az értékátlagosan 10 körül alakul (Coyle et al., 1992). Ez alapján az Alkatrész Kft. számára javasolt lenne erőforrásokat fordítani a fordulatszám növelésére. Ha egy cég raktárkészlete ugyanolyan mértékben, vagy gyorsabban nő, mint az értékesítése, akkor valószínüleg szükséges felülvizsgálni a készletezési politikáját. Általában, ha egy vállalkozás növekvő keresletet tapasztal a bizonyos termékei iránt, akkor hajlamos azokat túlkészletezni. Ehelyett azonban talán alkalmasabb megoldás lehet a beszerzési folyamat fejlesztése.

A készletezés hatékonyságának mérését szolgáló további eszköz a készlethatékonysági mutató. A készlethatékonyság azt mutatja meg, hogy $100 \mathrm{Ft}$ forgalom lebonyolításához milyen mennyiségü árukészletre van szükség, illetve 100 Ft forgalom lebonyolításához mennyi készletre van szükség. A készlethatékonyság akkor kedvező, ha változatlan forgalom mellett csökken az igénybe vett készlet nagysága, illetve egy adott készlettartás mellett nő a forgalom (Bíró et al., 2005). 
Ennek kiszámítása a következőképpen történik:

Készlethatékonyság $=\frac{\text { átlagos készletérték }}{\text { értékesítési forgalom }} \cdot 100$

$\mathrm{Az}$ Alkatrész Kft. készlethatékonysági mutatójának alakulását a 2. táblázat szemlélteti.

\section{2. táblázat: Az Alkatrész Kft. készlethatékonysági mutatója} 2015-2016 években

\begin{tabular}{|l|c|c|c|}
\hline & 2015. év & 2016. év & Index (\%) \\
\hline Készlethatékonyság & 0,6 & 0,5 & 83,3 \\
\hline
\end{tabular}

Forrás: Saját számítások eredményei (2017)

A készlethatékonysági mutató azt mutatja a vizsgált cég esetében, hogy árbevételét 0,5-szeres átlagos készletállománnyal érte el a társaság. A készletek állománya csökkent az előző évhez viszonyítvaa, a nettó árbevétel pedig növekedett. A két tényezỏ változásának hatására módosult a készlethatékonysági mutató.

\section{Az eredmények értékelése}

Jelen cikk célja az volt, hogy egy átfogó képet adjon azokról a kérdésekröl, amelyekkel az Alkatrész Kft. a beszerzési és készletgazdálkodási döntései kapcsán szembesül, továbbá gondolatébresztöként szolgáljon arra vonatkozóan, hogy a szervezet előtt milyen lehetőségek állnak ezek megválaszolására.

Összességében megállapítható, hogy a vizsgált cég készlethatékonysági mutatói nem túl versenyképesek az érintett gazdasági szektor kereskedelmi mutatóihoz viszonyítva, de ez még nem ad okot komoly aggodalomra. Ami a készletgazdálkodást illeti, három kulcsfontosságú elemet lehet kiemelni, amelyek a versenyképesség növeléséhez leginkább szükségesek:

a) $\mathrm{Az}$ első egy áruazonosító rendszer. Ennek előnyei a készletek bevételezésében, nyilvántartásában és az értékesítésben is jelentösek.

b) A második készlet-nyilvántartási rendszer. Ezzel kiküszöbölhetők a humán jellegü hibaforrások, és kiválóan alkalmas az üzletek és a raktárak közötti összeköttetés megvalósítása.

c) A harmadik a raktárkészlet korszerüsítése az aktuális keresleti igényekre vetítve.

Az Alkatrész Kft. az imént felsorolt három kulcstényezöből az első kettöt már kiépítette, tehát jó úton halad a versenyképessége javításához. A további fejlödés érdekében célszerü lenne a termékek értékesítésének fellendítésre megfelelö marketing stratégiát alkalmazni, valamint mielöbb értékesíteni a nagy értékủ speciális gyártású termékeit a készletek forgási sebességének növelése érdekében. Ezen felül ajánlott lenne a készletezésre használt szoftver továbbfejlesztése, hogy alkalmas legyen az egyes termékek optimális mennyiségének és tárolási helyének meghatározására is. Hiszen a túl magas készletszint felhalmozása megnöveli a munkaerö, a raktár, és az eszközkapacitás kihasználtságát. 


\section{Irodalomjegyzék}

Adorján Cs., Lukács J., Róth J., Veit J. (2009): Pénzügyi Számvitel-feladatok. MKVKOK Kft., Budapest.

Babbie E. (1999): A társadalomtudományi kutatás gyakorlata, Balassi Kiadó, Budapest.

Bányainé T. Á., Illés B., Korponai J. (2016): Az igényváltozások hatása a vásárolt alkatrész készletekre és a költségekre. Repüléstudományi közlemények, 28 (2): 15-32.

Bíró T., Fridrich T., Kresalek P., Mitró M. (2005): Számviteli kézikönyv 2005, Unió Kiadó, Budapest.

Bíró T., Kresalek P., Pucsek J., Sztanó I. (2012): A vállalkozások tevékenységének komplex elemzése. Perfekt Zrt., Budapest.

Coyle, J., Langley, J., Bardi, E. (1992): The Management of business logistics. West Publishing Company, Minneapolis.

Gál J. (2008) A logisztika alapjai, (Alapfogalmak, alapösszefüggések), IM Informatikai Magániskola Kft., Hómezővásárhely

Kardos P., Szakács I., Tóth M. (2012): A számvitel nagy kézikönyve. Complex Kiadó Kft., Budapest.

Koltai T. (2006): Termelésmenedzsent. Typotex Kiadó, Budapest.

Korom E., Ormos M., Veress A. (2005): Bevezetés a számvitel rendszerébe. Akadémiai Kiadó, Budapest.

Kövesi J. (2009): Menedzsment és vállalkozás-gazdaságtan, TYPOTEX Kiadó, Budapest.

Majoros P. (2004): A kutatásmódszertan alapjai, Perfekt Zrt., Budapest.

Szakács I. (2009): Számvitel A-tól Z-ig. Complex Kiadó Kft., Budapest.

Zsótér B., (2008): Application of a new method in compilation of a settlement monograph. Agrár-és Vidékfejlesztési Szemle, 3 (1): 1-6.

Zsótér B., Schmidt A., Trandafir N. (2014): Research of statisfaction related to investments (20062010) accomplished by the local council in Sandorfalva for durable development Quaestus: Open Access Journal, 5 (3): 107-114.

Zsótér B., Tóth A. (2014): Examination of statisfaction related to investments (2006-2011) accomplished by the local council in Abony. Analecta Technica Szegedinensia, 8 (1): 33-37. 